\title{
ENSINAR PARA APRENDER A VIVER EM UM NOVO MUNDO
}

Célia Lucena ${ }^{1}$

\section{Resumo:}

Trata-se de algumas notas sobre uma pesquisa exploratória sobre o Programa Raízes da Cidade, experiência realizada pela ONG Migraflix em parceria com AIRbnb. O objetivo do programa é oferecer oportunidades de realização de atividades que transformem habilidades e saberes em emersão cultural e educativa no país de destino. Três experiências junto a refugiados sírios foram analisadas. Este estudo mostra o refugiado buscando maneiras de transitar em novo mundo, usando a arte de ensinar como oportunidade de ganhar sustento e de se integrar. Dessa maneira, aulas de dança, de receitas culinárias e do idioma árabe são realizadas.

Palavras-chave: Refugiados. Táticas. Ensinar/Aprender.

\begin{abstract}
:
These are some notes on exploratory research at the Raízes da Cidade Program experience carried out by the ONG Migraflix in partnership with AIRbnb. This program aims to offer opportunities to carry out activities that transform skills and knowledge into cultural and educative emergence in the country of destination. Three experiences with Syrian refugees were analysed. This study shows the refugee looking for a way to move into a new world, using the art of teaching as an opportunity to earn a living and to integrate. In this way, dancing lessons, culinary receipts and Arabic language teaching are performed.
\end{abstract}

Key Words: Refugees. Tactics. Teaching. Learning.

A proposta deste artigo é revelar alguns dados de uma pesquisa exploratória junto de organizações de migrantes na cidade de São Paulo. A investigação teve como objetivo a elaboração de um subprojeto, ou seja, uma atividade empírica junto ao projeto temático Migrações e Identidade. Trata-se de um grupo de estudos vinculado ao CERU-USP, que, desde 2015, se reúne mensalmente para discutir e estudar questões migratórias contemporâneas. O grupo vem se dedicando a estudos teóricos sobre deslocamentos contemporâneos, a atividades empíricas, à apresentação de trabalhos em congressos e publicação de artigos em dossiê sobre migrações. A equipe estabelece parcerias com estudiosos na temática, com grupos de estudos de outros departamentos, universidades e de instituições de apoio a migrantes.

Ao buscar refugiados com intenção de dar avanço na investigação deparei-me com a proposta da ONG Migraflix (criada em 2015) em parceria com Airbnb, o "Programa Raízes da

\footnotetext{
${ }^{1}$ Célia Lucena. Doutora em História Social. Pesquisadora do NAP/CERU (Centro de Estudos Rurais e Urbanos), USP/SP. Mediadora do Grupo Migrações e Identidades (CERU-USP). Com investigações nos temas migrações, identidade, cultura e memória.
} 
Cadernos CERU, Série 2, Vol. 31, n. 1, jun. 2020

Cidade", cujo objetivo é integrar refugiados e migrantes social e economicamente. Vale lembrar que refugiada é uma modalidade migratória. A proposta da Migraflix é oferecer oportunidades de realizar atividades que possam transformar seus talentos, habilidades e saberes em emersão cultural e educativa no país de destino. Os migrantes no país de destino procuram se unir em associações estruturadas com o objetivo de se integrarem, de serem aceitos como membros de pleno direito e de obter reconhecimento de sua identidade étnica. Algumas redes de apoio e de ajuda oferecem programas e treinamentos para o "empreendedorismo étnico", conceito bastante discutido na atualidade que merece algumas reflexões. Assim, algumas ONGs abrem caminhos nessa direção. Para Halter (2007), o empreendimento étnico, além de ser uma escola de empreendedores, é uma escola de mobilidade social, de contexto de solidariedade e de interação cultural.

A participação no "Programa Raízes na Cidade" vem permitindo conferir algumas das experiências especificamente de sírios. O grupo de refugiados sírios, nos últimos anos, vem criando em São Paulo um nicho étnico, que adquire visibilidade ao exibir em feiras as habilidades culturais migradas da Síria. O refugiado mantém o duplo vínculo de suas práticas: de um lugar próprio (um patrimônio) e um princípio coletivo (a família e o grupo). O que acontece quando esse duplo postulado está ausente?

O migrante, "sem sair do lugar onde tem que viver e que lhe impõe uma lei, ele aí instaura pluralidade e criatividade e lida com imprevistos" (Certeau, 1994, p.93). As operações multiplicxam-se com a extensão dos fenômenos de assimilação ou aculturação, ou seja, os deslocamentos que substituem maneiras ou "métodos" de transitar pela identificação com o lugar. Para essa arte muito antiga de "fazer com", dá o nome de usos, trata-se de ações que são a sua "inventabilidade" própria. As táticas apontam para uma hábil utilização do tempo, das ocasiões, o que permite caracterizar as táticas como "polemologia" do fraco. São do tipo prático as atividades cotidianas: habitar, circular, falar, dançar, ler, ir às compras, ensinar, cozinhar, gestos hábeis do "fraco" na ordem estabelecida pelo "forte" (CERTEAU, 1994).

\section{Refugiados usam a arte de ensinar para transitar em um novo mundo}

De acordo com a Lei 9474/1997, denominada Estatuto Nacional do Refugiado, reconhece como tal todo indivíduo que: I- devido a fundados temores de perseguição por motivos de raça, religião, nacionalidade, grupo social ou questões políticas encontra-se fora de seu país de nacionalidade e não possa ou não queira acolher-se à proteção de tal país; II- não tendo nacionalidade e estando fora de seu país onde antes teve sua residência habitual, não possa ou não queira regressar a ele, em função de circunstâncias descritas em inciso anterior; III- devido à grave e generalizada violação de direitos humanos, é obrigado a deixar seu país 
Cadernos CERU, Série 2, Vol. 31, n. 1, jun. 2020

de nacionalidade para buscar refúgio em outro país ${ }^{2}$. A Lei 9474/1997 criou o CONARE (Comitê Nacional para os Refugiados), órgão presidido pelo Ministério da Justiça e atua nas questões pertinentes à concessão de refúgio e integração dos refugiados.

A partir da ausência de proteção do próprio Estado e da violação dos direitos humanos dos indivíduos nacionais, o refugiado se origina. A proteção internacional dos refugiados torna-se, então, papel não apenas dos Estados, mas também das Nações Unidas, das organizações internacionais e regionais, e da sociedade civil. (CALEGARI, 2018).

$O$ refugiado, buscando maneiras de transitar em novo mundo, instaura criatividade por meio da arte da memória e da ocasião em país de destino. Assim, fazem uso de didática, de metodologia, de planejamento com intuito de transferir habilidades do país de origem, como campo de conhecimento, como oportunidade para ganhar seu sustento e ainda como forma de integração no país de acolhida. Nesse sentido, está sendo instigante verificar as artes de ensinar realizadas pelos refugiados como forma de convívio, sobrevivência e integração. E conferir como tal aprendizagem se processa em contexto amplo com o objetivo de inserção em país de destino.

Objetiva-se conferir como acontece a transferência das habilidades, como essas pessoas são transplantadas; uma vez não consideradas desenraizadas (THOMSON, 2002), como replantam sua cultura no país de destino? Perceber como os usos e táticas utilizados no país de destino dinamizam as identidades, levando em conta que as identidades contemporâneas são movediças, contraditórias, "de tal modo que as identificações estão sendo continuamente deslocadas" (HALL, 2015, p.12). E verificar ainda de que maneira se apropriam do aprendizado transmitido pelas ONGs. As modalidades migratórias contemporâneas estão associadas à emergência de políticas de identidade para incluir aqueles que fazem o trajeto da emigração para a imigração. As identidades fragmentam-se, apoiam-se em redes sociais e se transformam em cidadãos desterritorializados. A sociedade global leva a múltiplas identidades e pertencimentos transnacionais, gera sociedades multiculturais e identidades transnacionais. Assim, a sociedade multicultural admite justaposição de etnias e diversidade de culturas.

Em "Aprenda a fazer o pão caseiro da Síria", em "Viagem a Damasco" e em "Dança Ritual do Oriente Médio", três experiências oferecidas pela Migraflix defrontam-se com protagonistas que fazem parte dos 5,5 milhões de refugiados no mundo. O deslocamento da população síria é reflexo dos conflitos gerados com a guerra civil síria. A guerra civil síria teve início, em 2011, com protestos e mobilizações populares, como reflexo de outros movimentos

\footnotetext{
${ }^{2}$ Texto baseado em Seminário de 09 de março de 2020, conduzido por Geraldo de Sá no grupo de pesquisa: Migrações e Identidade (CERU-USP).
} 
Cadernos CERU, Série 2, Vol. 31, n. 1, jun. 2020

no mundo árabe, denominados Primavera Árabe. Nos protestos em questão, a população síria exigia maior atenção aos direitos humanos, mais liberdade, mais democracia, uma nova legislação e a queda do presidente Bashar al-Assad. A disputa entre os diversos grupos levou a uma guerra civil caracterizada por grande violência e violação dos direitos humanos.

De acordo com as estatísticas (ACNUR, 2017) ${ }^{3}$, há cerca de 22.5 milhões de refugiados no plante. A principal nacionalidade é a síria, com aproximadamente 5,5 nilhões de refugiados no mundo.

Desde o começo do conflito sírio, em 2011, até o final de 2016, foram 3772 solicitações no Brasil por sírios. A recepção de sírios foi facilitada por meio da Resolução Normativa n. ${ }^{\circ}$ 17, a qual foi adotada em setembro de 2013 pelo CONARE (Conselho Nacional para Refugiados) e renovada em setembro de 2015, para desburocratizar a emissão de vistos, que concede, por razões humanitárias, o visto apropriado. Nos últimos anos, o Brasil afirmou-se como o principal país de destino, na América Latina, para refugiados sírios.

As experiências realizadas por refugiados no "Programa Raízes da Cidade", da ONG Migraflix, viabilizam atividades com base na troca da cultura migrante com brasileiros, em workshops de culinária, música, dança, arte, serviço de catering e palestras. Os projetos são realizados em parceria com Acnur ${ }^{4}$, com setor privado, com Google, Linkedin e Airbnb. As atividades com sírios revelam que a alimentação e o idioma são caracteres selecionados pelos refugiados como repertório de suas táticas. Essas táticas não obedecem a lei do lugar. Para Certeau, "as estratégias são capazes de produzir, mapear e impor, ao passo que as táticas só podem utiliza-los, manipular e alterar" (1994, p.92). As práticas escolhidas definem o habitus incorporado na primeira infância e são maneiras de fazer transferidas em malas de migrantes.

A experiência "Aprenda a fazer o pão caseiro da Síria" é realizada por Fátima, muçulmana, curda, natural da Síria, da cidade de Aleppo. Antes de se deslocar para o Brasil, viveu quatro anos na Jordânia. Em 2014 transferiu-se para São Paulo com marido e quatro filhos, tem uma quinta criança que nasceu no Brasil. O nascimento de criança no país de destino, na maioria das vezes, é uma estratégia para legalização da documentação. Justifica a escolha pelo Brasil pela facilidade encontrada na conquista do visto. Segundo a protagonista, o visto para o Brasil foi simples e barato, sobre isso diz: "O governo brasileiro ajuda pouco, na Europa também governo ajuda pouco, mas o brasileiro é gente boa, tem muita gente com o coração bom, que dá força para você”. Afirmou que os irmãos encontraram refúgio em países europeus

\footnotetext{
${ }^{3}$ ACNUR, agência da ONU para refugiados.

${ }^{4}$ ACNUR, agência da ONU para refugiados.
} 
Cadernos CERU, Série 2, Vol. 31, n. 1, jun. 2020

e um deles se fixou no Canadá. Na Síria restou a mãe em companhia de um irmão que não migrou por conta de problemas não resolvidos com o passaporte.

Em sua fala rememora Aleppo, como sendo o coração da Síria. Mantém a lembrança de um lugar com plantação de algodão e de fábricas de roupas e tecidos. Cidade que oferecia emprego para a população local. Em sua cidade era grande o número de mulheres jovens que trabalhavam em fábricas, prática essa que faz contraponto ao discurso de que as mulheres árabes em geral se dedicam à casa e à família. Ao falar da casa em que vive em São Paulo, rememora a casa da mãe, o projeto do sobrado faz lembrar a casa do passado, a casa da mãe em Aleppo.

Fátima, em sua própria residência, ministra várias aulas semanais sobre o pão caseiro denominado saj. Inicia a aula fornecendo orientação aos alunos sobre a quantidade de farinha, água e sal, chama a atenção para o fato de que no pão não vai fermento, tampouco óleo e manteiga. Sobre o significado do pão na cultura síria, diz:

Na minha terra, quando alguém entra na casa da gente, antes de fazer oração, vai comer esse pão. Gente que vem na minha casa eu compartilho comida. Se alguém pensa em fazer coisa ruim, depois de você oferecer pão com sal, ele não pode mais fazer o mal. ${ }^{5}$

O alimento tem um valor simbólico, é oferecido aos visitantes e a concordância entre a avaliação do hospedeiro e do hóspede significa o reconhecimento das relações harmoniosas na Síria.

Enquanto o grupo manuseia a massa conta sua trajetória e a guinada de vida, após a guerra da Síria. Conta que o pão na Síria é muito barato. Porém, depois do início da guerra, com dificuldades com falta de gás, recuperaram a prática do pão feito em casa e mantido em freezer. Assim, continua seu relato:

Aprendi a cozinhar desde cedo e acredito que a comida une e deixa as pessoas à vontade ao redor da mesa. No nascimento do bebe, no momento da morte $\mathrm{e}$ no casamento são celebrados com café e muita comida. ${ }^{6}$

Enquanto a massa descansa, café e petiscos são degustados. Ao som de músicas árabes alguns passos de dança são ensinados. As conversas entre a mestra e os participantes giram em torno de receitas e das diferentes formas de fazer. Algumas inventivas culinárias testadas em São Paulo foram mencionadas por Fátima, como o feijão que tempera com romã, tahine e azeite de oliva. Dá explicações sobre as combinações dos acompanhamentos e a importância do pão em determinados pratos.

A experiência "Viagem a Damasco" é organizada por Yamam, muçulmana, que veio da Síria, da cidade de Damasco, em 2016, com ajuda de Mohamad, noivo que desembarcou em

\footnotetext{
${ }^{5}$ Depoimento de Fátima coletado em sua residência, em novembro de 2019.

${ }^{6}$ Depoimento de Fátima coletado em sua residência, em novembro de 2019.
} 
Cadernos CERU, Série 2, Vol. 31, n. 1, jun. 2020

São Paulo em 2015, ambos se conheceram no Brasil. Yamam é formada em arqueologia e trabalhava no Museu Nacional de Damasco. Tem receio de que aconteça algo com a mãe e amigos que permaneceram em Damasco.

Aos domingos Yamam e o noivo recebem clientes para um almoço cultural, durante o qual um vídeo sobre a parte antiga e histórica da cidade de Damasco é exibido. Numa dinâmica de workshop muitas histórias são narradas. As imagens registram lugares históricos e os anfitriões usam de conhecimento para explicações sobre as várias civilizações que habitaram o território. Todavia, a guerra não é exibida, tampouco comentada.

Yaman e Mohamad, durante a semana, no mesmo espaço em que é servido o almoço, oferecem aulas de árabe a brasileiros, tendo o pequeno apartamento já adquirido fisionomia de escola de idioma, com cartazes e tecnologia específica. Fátima, por sua vez, ocupa-se no dia-adia com a entrega de encomendas de comidas árabes para clientes, o serviço que recebe o nome de catering. Em suma, as duas experiências de mulheres empreendedoras utilizam-se de comida, de práticas do tipo tático, exibem suas habilidades culturais em busca de êxito econômico.

Já Yara Tanji, palestina nascida na Síria, há um ano veio para o Brasil encontrar a família que vive aqui há três anos, é especialista em iniciação de ballet clássico e dança árabeandaluz (tipo de dança utilizado em rituais) oferecendo a experiência "Dança Ritual do Oriente Médio". É professora de dança e advogada. Foi bailarina e se apresentava para grandes plateias internacionais, participou de seriados e filmes produzidos na Síria. Utiliza um aquecimento dos músculos e a seguir introduz os alunos no mundo mágico da dança oriental. Segundo Yara, a música transporta os participantes a outros tempos e lugares, por meio da dança as pessoas podem captar energia positiva.

A dança, arte de movimentar o corpo em certo ritmo, é uma arte cênica caracterizada por movimentos. A dança é arte e expressa emoção, sentimentos e cultura local. No caso de São Paulo, cidade que prima pela diversidade cultural, é de suma importância utilizar arte como processo educacional. Utilizar diferentes ritmos é uma forma de lidar com habilidades culturais e de obter informações e novos olhares sobre a cultura do outro. 
Cadernos CERU, Série 2, Vol. 31, n. 1, jun. 2020

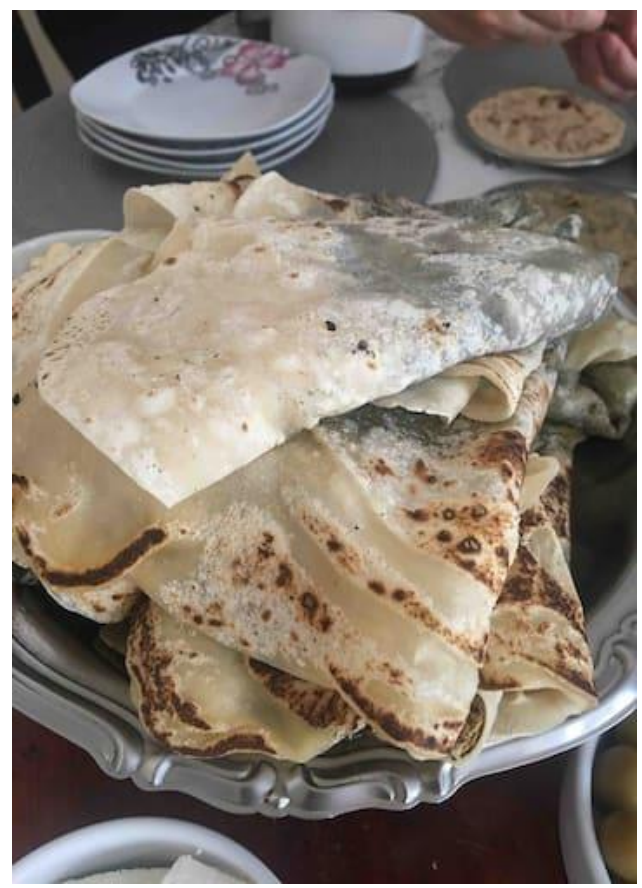

Foto 1 - Aprenda a fazer o pão árabe

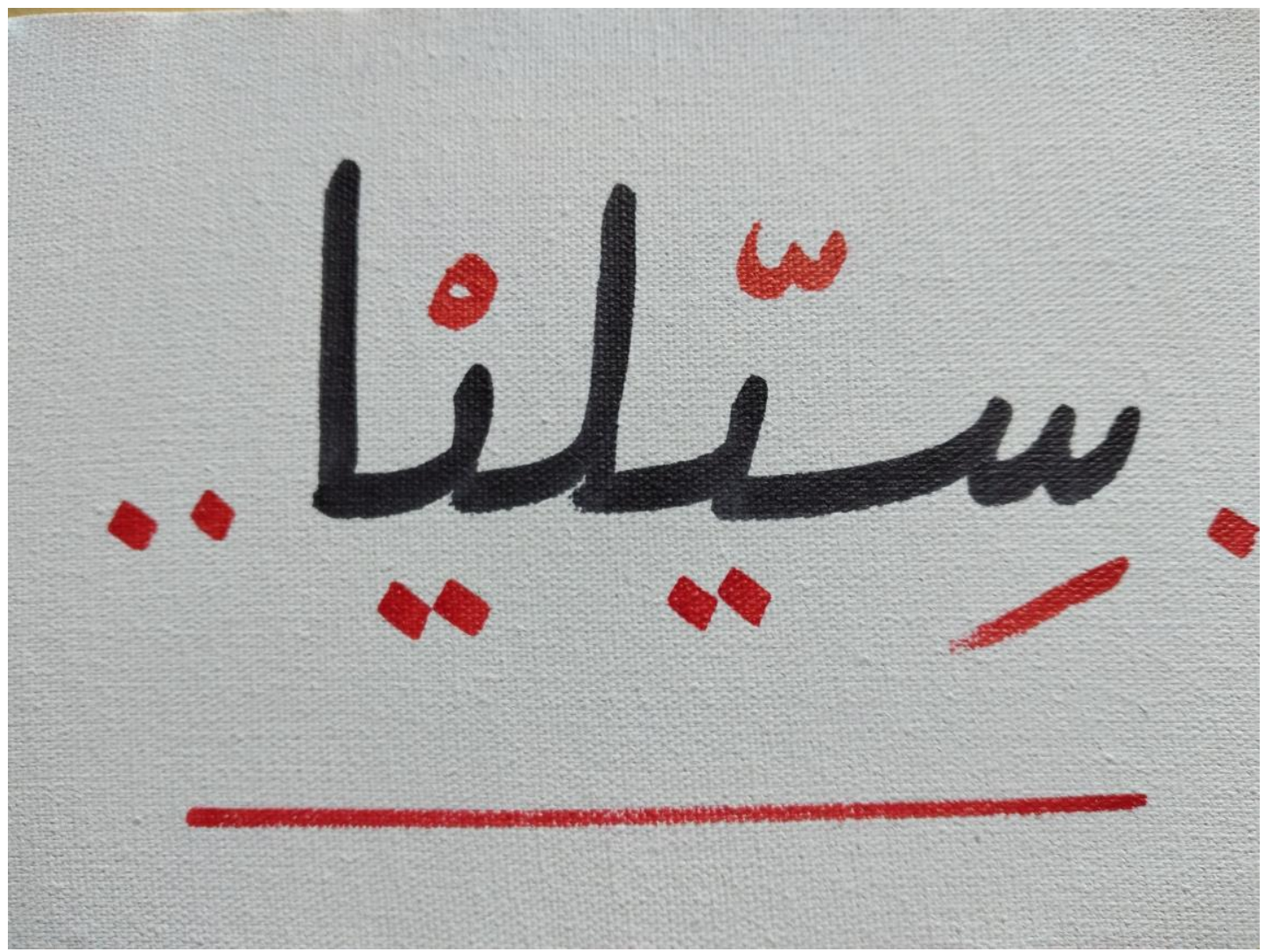

Foto 2 - Viagem a Damasco 
Cadernos CERU, Série 2, Vol. 31, n. 1, jun. 2020

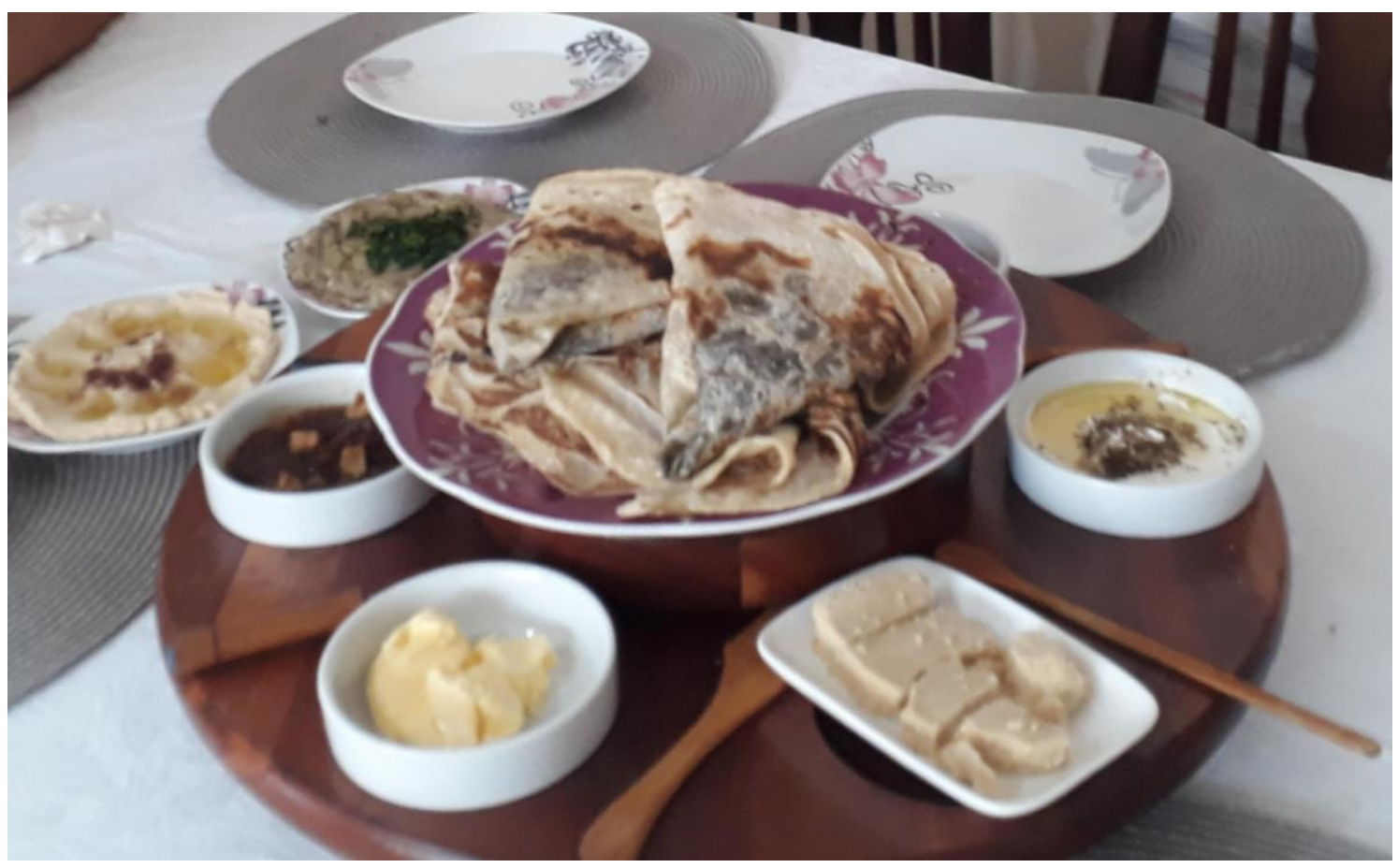

Foto 3 - Aprenda a fazer o pão árabe

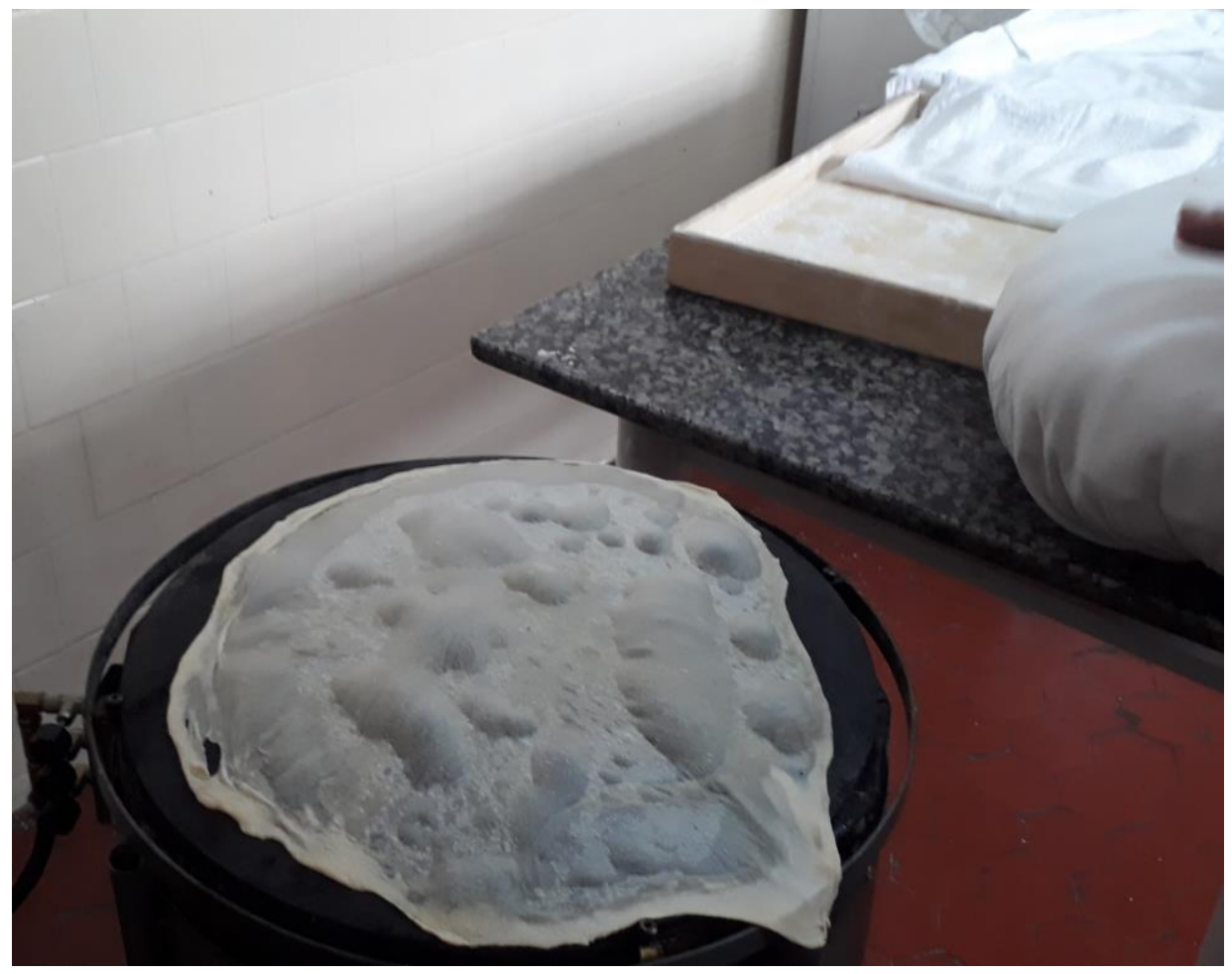

Foto 4 - Aprenda a fazer o pão árabe 
Cadernos CERU, Série 2, Vol. 31, n. 1, jun. 2020

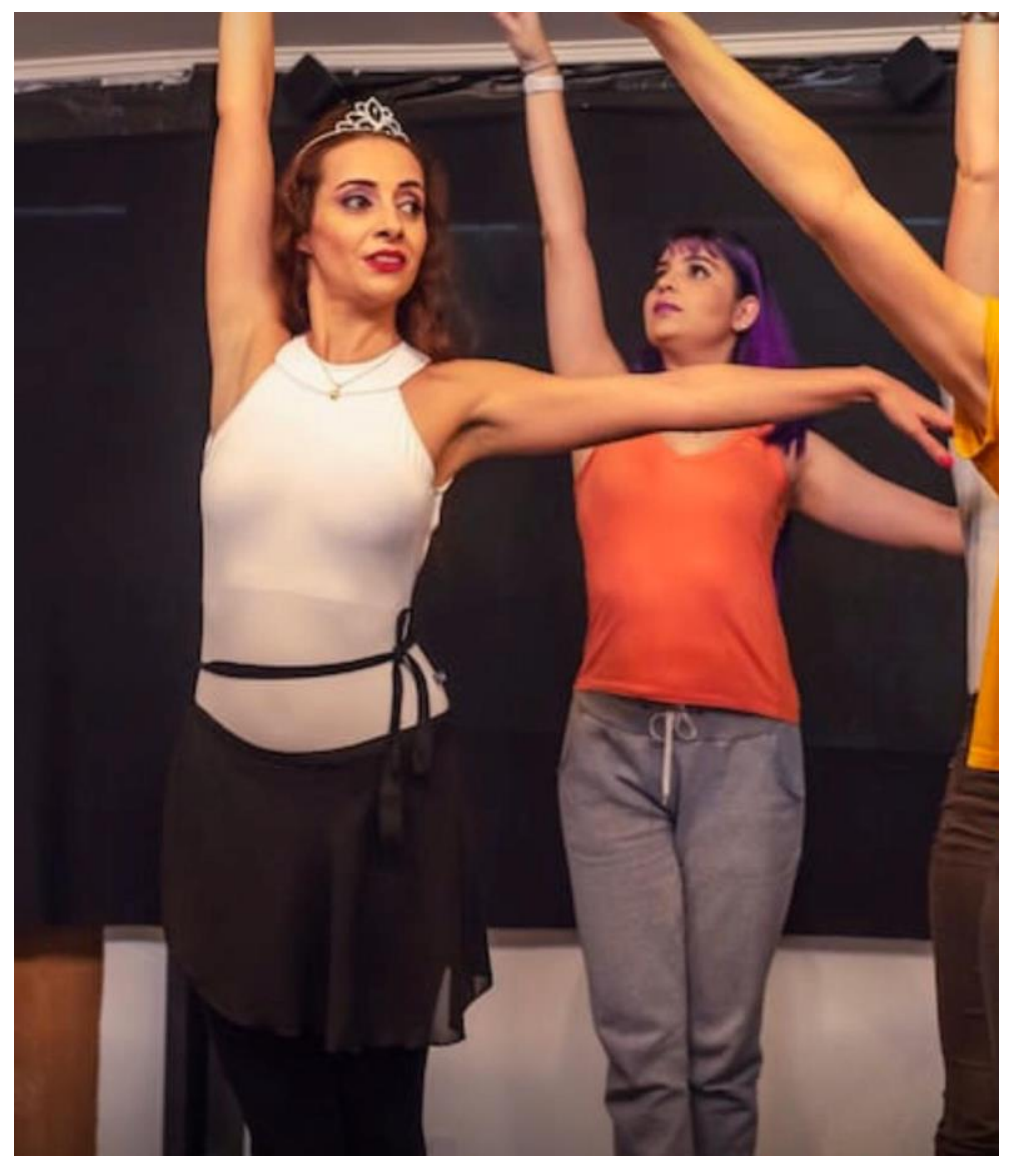

Foto 5 - Dança ritual do Oriente Médio

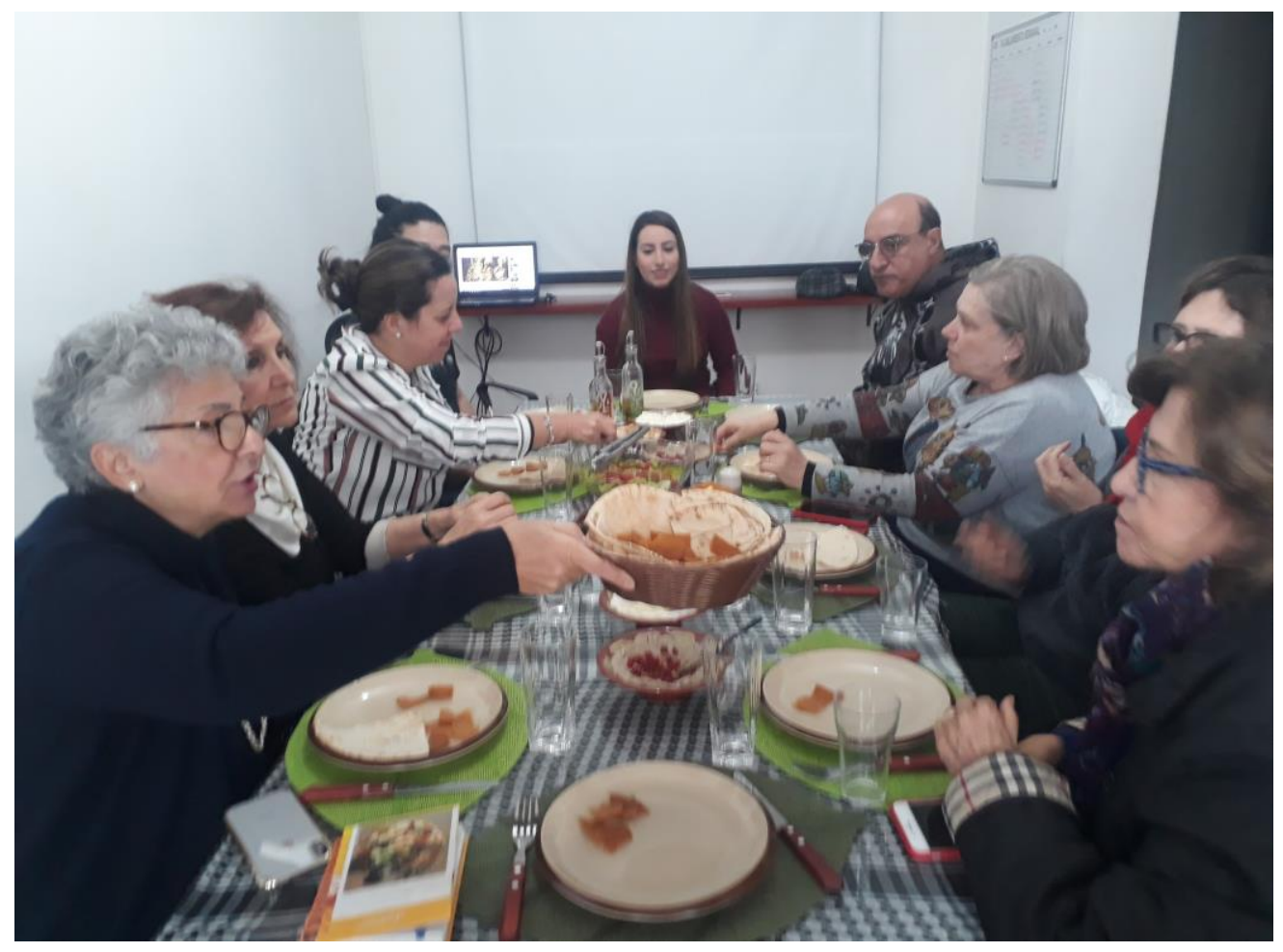

Foto 6 - Viagem a Damasco 


\section{Algumas habilidades e criatividades em país de destino}

No decorrer da pesquisa, com o intuito de conferir algumas habilidades e criatividades de mulheres sírias na cidade de São Paulo, fontes estão sendo construídas por meio de entrevistas orais, registros fotográficos, de observação participante ao vivenciar as respectivas experiências. A oralidade tem tido um papel fundamental na relação com o outro. A conversação tem sido o ponto chave para estabelecer uma relação dialógica. O encaminhamento da investigação tem exigido uma reflexão constante. Conversas individuais, com estrutura flexível, permitiu-me escutar a voz de mulheres, elas falam do modo de organizar seu trabalho, de vivê-lo, de senti-lo. Assim, foi possível perceber o quanto dão importância a se7u saberfazer (GIARD, 1998). Informações, depoimentos e fotos encontradas no site (www.news.airbnb.com/br/ refugiados) foram instigantes, como também alguns teóricos eleitos como âncoras nas análises foram de grande valia.

Segundo Moulin (1975), comemos nossas lembranças temperadas de ritos, que marcam a primeira infância. O relato de Fátima vem ao encontro ao pensamento de Moulin: "Eu nasci na Síria e ainda menina aprendi os segredos do preparo dos pratos típicos de meu país sob o olhar cuidadoso de minha mãe".

Para Bourdieu (1979), o que diz respeito à comida são objetos que não sofrem influência no modelo escolar. Sendo assim, continua na trajetória de vida a mais estreita relação com o habitus recebido na origem. No lugar onde tem que viver, sob um universo cultural diversificado, nova língua e novas ordens impostas, o refugiado instaura criatividade. "Por uma arte de intermediação ele tira daí efeitos imprevistos." (CERTEAU, 1994, p. 93).

Para Gonçalves (2002), os gostos alimentares são os traços culturais mais permanentes, os mais resistentes às modificações. Apresentam uma dimensão de “longa duração". Os hábitos alimentares fazem parte de um domínio que implica representações e imaginários, essas práticas fazem com que atividades do passado e do presente se entrelacem, com base em uma tradição que se atualiza na elaboração dos pratos. Na ausência do duplo postulado: patrimônio (lugar de origem) e grupo familiar os refugiados priorizam a maneira de oferecer e partilhar. A comida se converte em um eixo que serve para ser reconhecido e se reconhecer em relação a seu grupo de pertencimento e em relação ao novo contexto. $\mathrm{O}$ ato de comer torna-se um relato nostálgico do país ou lugar de origem.

Para os migrantes, a natureza dos produtos utilizados nas comidas parece ser menos importante do que a maneira de prepara-la e, sobretudo, de consumi-los, de pensar o modo de servi-la, apresentar, oferecer e partilhar. Para Yamam, em substituição ao damasco fresco, utiliza o damasco seco, umedecido em água, para fazer o suco. Diz: "Não encontro a fruta fresca 
para comprar, então deixo o damasco seco de molho em água e depois bato no liquidificador"7. Fátima, referindo-se aos ingredientes, diz: "Falta muita coisa, a gente não acha". O condimento chave é o zatar, acompanha vários pratos; uma vez preparado por elas próprias, demonstra ser um tempero que carrega a marca familiar. O cardamomo, semente de sabor condimentada, acompanha o café.

Os frequentadores e alunos, tanto das aulas de árabe como das aulas de pão caseiro, são pessoas que buscam se reencontrar com seu país de origem (sírios de fluxos migratórios mais antigos), descendentes de segunda e terceira geração que procuram encontrar o país de seus ascendentes, comensais que buscam um paladar diferente, pessoas interessadas em estudar árabe e conhecer um alfabeto diferente. Professores(as) e alunos(as) de cursos de gastronomia buscam o curso de Fátima como oportunidade de aprender uma receita que marca singularidade. Uma participante comenta: "Voltarei com mais sede de aprender e principalmente trarei meus alunos de gastronomia. Pois, como chef de cozinha e docente, senti realizada neste encontro" ${ }^{\text {. }}$

Uma participante do curso de dança de Yara comenta:

Achei fantástico poder conhecer uma cultura diferente sem sair da cidade. Yara é uma bailarina profissional, a dança e a música síria são lindas. E ouvir o relato de sua história é muito tocante. Adorei. ${ }^{9}$

É instigante saber quanto as ONGs colaboram e abrem as portas para a inserção desses atores em local do destino; para isso existe a possibilidade de localizar protagonistas vinculados a outras ONGs, como também investigar sírios proprietários de restaurantes, recentemente abertos em São Paulo.

\section{Considerações finais}

Os exemplos analisados acima ilustram a complexidade da migração, fenômeno que transcende a inúmeros limites. A vivência de um grupo étnico no local de destino é um elemento instigante para conhecer a história da migração. A experiência de transmitir sua cultura, ensinar e adaptar suas receitas culinárias, ensinar o idioma e as danças do país de origem faz parte de táticas utilizadas no processo de aprender a viver em um novo mundo, são colisões entre antigos e novos costumes, evidencia a natureza mutável e os significados complexos da identidade na experiência dos migrantes (THOMSON, 2002). As migrações, refúgios e diásporas têm ampliado a reflexão além dos limites tradicionais para mostrar processos de aprendizagem nos quais as diferenças culturais se mesclam e se potencializam como fatores reivindicatórios e identitários (RODRIGUEZ, 2005).

\footnotetext{
${ }^{7} \mathrm{O}$ depoimento de Yamam foi coletado em seu espaço de aula de árabe, em agosto de 2019.

${ }^{8}$ Depoimento extraído do site www.news.airbnb.com/br/refugiados

${ }^{9}$ Depoimento extraído do site www.news.airbnb.com/br/refugiados
} 
Cadernos CERU, Série 2, Vol. 31, n. 1, jun. 2020

Muitas outras aulas são oferecidas por refugiados de diferentes locais, por meio da migraflix/airbnb, experiências que merecem estudo e análise. Entre elas: "Dança Zulu Too", "Bordado Boliviano-Artes Cholita", "Descubram o design dos tecidos africanos", "Dança e moda africanas com Miss Congo", "Ardor é escusa, coma comida mexicana", "Descobre a Venezuela, um doce gourmet”. Assim, refugiados e imigrantes transformam seus talentos em emersão cultural. Tais experiências passam pelas artes, pela dança, pela culinária, oferecendo ao público um aprendizado de culturas diferentes.

Viver entre duas culturas é uma característica da migração. A diversidade cultural surge da migração individual e familiar. Dessa maneira, os migrantes e refugiados transitam em linguagens culturais diferentes e apresentam identidades e identificações movediças (RODRIGUEZ, 2005; KYMLICKA, 1996; LUCENA, 2019). Trata-se do direito à diferença. A homogeneização trazida pela globalização é acompanhada de cenários de diferenças $e$ afirmação de etnicidade. As sociedades modernas apresentam cada vez mais grupos minoritários que exigem o reconhecimento de sua identidade e a acomodação de suas diferenças culturais. As práticas culturais vivenciadas em outro contexto estimulam a imaginação, a inventividade, a criatividade, a troca de informações e saberes. Dão oportunidade à sociedade civil do país de destino adquirir ares multiculturais. Atualmente, diversidade cultural, pluralismo cultural, sociedade multicultural e multiculturalismo são noções que constituem o eixo das discussões das identidades migratórias.

\section{Referências bibliográficas}

ACNUR. Statistical online database. Brasília (DF), 1917. Disponível em: http://www.unhcr.org BOURDIEU, P. La distincion: critique sociale du jugement. Paris: Minuit, 1979.

CALEGARI, M. Condições de vida dos refugiados sírios em São Paulo. In: BAENINGER, R. et alii. Migrações Sul-Sul. Campinas (SP): Núcleo de Estudos da População Elza BerquóNEPO/UNICAMP, 2018.

CERTEAU, M. A invenção do cotidiano: 1. Artes de fazer. Petrópolis: Vozes, 1994.

GIARD, L. Cozinhar. In: CERTEAU, M.; GIARD, L.; MAYOL, P. A invenção do cotidiano. 2. Morar, cozinhar. Petrópolis (RJ): Vozes, 1996.

GONÇALVES, J.R.S. A fome e o paladar: uma perspectiva antropológica. In: Seminário Alimentação e Cultura. Rio de Janeiro: FUNARTE/CNFCP, 2012. (Série Encontros e Estudos, 4).

HALL, S. A identidade cultural na pós-modernidade. Rio de Janeiro: Lamparina, 2015.

HALTER, M. Cultura econômica do empreendimento étnico: caminhos da imigração ao empreendedorismo. ERA-Revista de Administração de Empresas, vol.47, n.1, 2007.

KYMLICKA, W. Ciudadania multicultural. Barcelona: Paidós, 1995. 
LUCENA, C. Migrações contemporâneas e impasses identitários: algumas teorias e conceitos. Cadernos CERU, Série 2, vol.30, n.1, jun. 2019.

MIGRAFLIX/ AIRBNB. Programa Raízes da cidade. Disponível em: www.news.airbnb.com/br/refugiados

MOULIN, L. L'Europe à table: introduction à une psychosociologie des pratiques alimentaires. Paris/Bruxeles: Elsevier Sequoia, 1975.

RODRIGUEZ, M. L. Cultura y migración: los processos de naturalización de la diferencia. Migración, desplazamiento forzado y refugio. Quito: AECI, 2005.

THOMSON, A. Histórias (co)movedoras: História oral e estudos de migração. Revista Brasileira de História. São Paulo, v. 22, n. 44, p.341-364, 2002.

www.news.airbnb.com/br/ refugiados. 